\title{
Biofuel Energy for Mitigation of Climate Change in Ethiopia
}

\author{
Abreham Berta, Belay Zerga \\ Department of Natural Resource Management, Wolkite University College of Agriculture and Natural Resource, Wolkite, Ethiopia
}

Email address:

abresh1240@gmail.com (A. Berta), belayzerga@Gmail.com (B. Zerga)

To cite this article:

Abreham Berta, Belay Zerga. Biofuel Energy for Mitigation of Climate Change in Ethiopia. Journal of Energy and Natural Resources. Vol. 4, No. 6, 2015, pp. 62-72. doi: 10.11648/j.jenr.20150406.11

\begin{abstract}
There is a large interest in biofuels in Ethiopia as a substitute to petroleum-based fuels, with a purpose of enhancing energy security and promoting rural development. Ethiopia has announced a national biofuel production in the GTP in order to secure energy in the rural part and urban of Ethiopia. Its implications need to be studied intensively considering the fact that Ethiopia is a developing country with high population density and large rural population depending upon land for their livelihood. Ethiopia plan to reduce importing oil from foreign since the oil imported has huge potential of polluting the environment. Therefore, biofuel is free from pollutants; it is the main energy source for Ethiopia in the near future since Ethiopia economy is experiencing high growth rate, which may lead to enhanced demand for food, livestock products, timber, paper, etc., with implications for land use. The assessment is largely focused on first generation biofuel crops, since the Ethiopia program is currently dominated by many biofuel crops/trees, the process of biofuel and the relation environment and climate mitigation potential of biofuel. Technological,policy options, awareness creation required for promoting sustainable biofuel production in Ethiopia as recommendation from the review study.
\end{abstract}

Keywords: Biofuel, Climate Change, Mitigation, Oil, Petroleum

\section{Introduction}

Currently, worldwide annual energy use exceeds 9 billion tons of oil (e.g. fossil fuel). Of this, transport energy is responsible for 1.8 billion tons $(20 \%)$ and results in over 6.3 billion tons of Carbon Dioxide $\left(\mathrm{CO}_{2}\right)$ emissions (WBCSD and EEA, 2004). There is an appetite for action on climate change. But global warming has not been reduced to safe levels(UNEP, November 2010) The world is currently on track for warming of at least 3 to $4 \mathrm{oC}$ by 2100,14 which would have far reaching consequences for food security, fresh water availability, and the frequency and intensity of storms(Intergovernmental Panel on Climate Change, 2014). At this level of climate change, the efficacy of adaptation strategies would be severely limited.

That is why the Paris summit 2015 is important because a strong international agreement will: allow countries to push ahead with strategies and policies for carbon emissions reduction, knowing that others are doing likewise; provide a predictable framework for a global low carbon economy; allow developing countries to pursue low carbon development strategies and adapt to the effects of climate change; improve international efforts to protect the natural environment(Rebecca Willis, 2014).
In response to the need for more sustainable forms of energy many new technologies have been introduced. In many countries the use of biofuel focuses on ethanol and biodiesel (i.e. Jatropha and Castor been etc.) has increased significantly in recent years (Tobin, 2005).

International Energy Agency research warns that delayed action would result in substantial additional costs, as high carbon investments made now would quickly lose their utility and value(OECD, 2014)

The last few years have witnessed both a dramatic increase in the price of oil and an increase in the production of biofuels like ethanol and biodiesel (Martinot, 2005).In many African countries there is a numerous political drive to establish domestic fuel industries. Biofuels are being up as the solution to rise fossil fuel import, to rural development, to the climate change challenge and all manner of other national development priorities (UNCT Ethiopia, 2008). Biofuel has several advantages over fossil fuels especially in landlocked countries likeEthiopia.

Recent trends also show that interest in biofuels is expanding towards developing countries where production costs are relatively inexpensive and gives possibility for biofuel to contend with fossil fuel prices. Currently, Ethiopia's economic and social development efforts are geared towards 
raising the country to a middle income level within the coming 20 years. To this effect every sector pursues its own targets since the vision is of national interest. Energy development, if designed in line with the needs of agriculture, industry, transport and other related sectors, would highly accelerate the achievement of this goal. (FFE, 2008).

Ethiopia's energy consumption is predominately based on biomass energy sources (94\%).Traditional Energy Sources are Fuel wood, Charcoal, dung. Modern Energy is mainly products of petroleum and Electricity and Petroleum product is the major part from modern energy and it is mainly used for transport sector. The major source of electricity is hydro power plant. Ethiopia has potential of more than 45,000 MW from hydropower, Geothermal resource potential is estimated $1070 \mathrm{MW}$, Coal reserve is 70 Million Tons and Natural Gas Reserve 4 TCF (Terra Cubic Feet). Estimated potential of biogas cogeneration is greater than $263 \mathrm{MW}$, Woody biomass 787 Million tones Solar, wind and animate energy potential exist at considerable $\mathrm{s}$ size. There are huge potential on biofuel such as ethanol and biodiesel, currently 8 million liters of ethanol and huge potential of biodiesel in Ethiopia (Melis Teka, 2006).

The initiative for biofuels development in Ethiopia originally came from the private sector, though it did not take too long to get the government to buy-in. Mitigation of climate change is often presented by governments as a key policy goal for biomass fuel developments, but in the case of Ethiopia, the government is explicit about its reasons for promotion of biofuels. The reasons, among others, are energy security through the use of biofuels and to improve the balance of trade by import substitution and new export market development (Ministry of Mines and Energy, 2008).

Ethiopia has suitable environment for the growth of biofuel plants. It mean that Ethiopia has apple and fertile land, water resource and man power but have no technology, skill and experience of biofuel extraction.

The overall Objective of the study is assessment or review of biofuel production for mitigation of climate change in Ethiopia condition.

Significance of the study

There is an opportunities for the growth of biofuel crop like jatrohpa, caster bean, sugarcane, maize to produce ethanol and biodiesel but the imported energy like petroleum and coal require high price that affect economic development of Ethiopia and the energy produce from biofuel is free from emission of gases to the atmosphere. There is also $85 \%$ of the Ethiopia communities are living in rural area and their lively hood is dependent on agriculture then this new getting form of energy is not understand by the communities of Ethiopia. Even the process of biofuel to produce biodiesel or ethanol is lack of knowledge in Ethiopia. What types of crops are used for ethanol or biodiesel, how propagate or multiplication the species for the sustainability of biofuel and the relation of biofuel with environment especially climate change mitigation is not clearly understand by Ethiopian society. This assessment research is avoiding the gap between all the above mentioned problems.

\section{Data Requirements and Sources}

This study has used data from primary and secondary sources. The primary sources of data were of Jatropha in benishangulgumze region of Ethiopia the two companies, Amabasel Jatroph Project and Sun Biofuels Eth/NBC the land coverage and their objectives as well as the production systems. All the necessary data regarding Jatropha cultivation and processing that are used to assess the energy balance, GHG effect and financial and economic feasibility of Jatropha production interviewed the companies.

The secondary data was collected from the following relevant sources: Agriculture and rural development offices at local and regional level, Ethiopia, minster of Environmental and forestry at deferent levels of Ethiopia, Swiss ministry of energy, irrigation and water of Ethiopia, Published and unpublished materials and internet. Personal observation and informal discussions with out-growers and biofuel developers' were used to generate primary data. After getting the data, there could be compiling in coherent form as reviewer of bio-fuel energy for climate change mitigation.

\section{Literature Review}

\subsection{Biofuel Crops and Technologies}

Traditionally solid-biomass (fuel wood and agro-residue) has been used as a source of energy for cooking, heating and even for power generation. Biofuel is another application of biomass. There are many sources of biomass feedstock for biofuel production, which include sugar crops, starchy crops, cellulosic material and oil crops, which are presented in Fig. 1 (FAO, 2008). However, the expansion of biofuel crops for the production of liquid biofuels for transport, in the recent years, is largely based on agricultural crops as feedstock such as sugarcane and maize for ethanol production and oil palm, soybean and rapeseed for biodiesel production. For example $85 \%$ of the global production of biofuels is in the form of ethanol from sugarcane and maize, where Brazil and USA accounts for $87 \%$ of global ethanol production (FAO, 2008).

\subsection{Policy and Strategy of Ethiopia Government on Biofuel}

It was planned during the PASDEP period to distribute 3 million improved energy saving biomass ovens these have been distributed as planned. As result it is estimated that about 26176 ha of forest have been conserved from deforestation and carbon dioxide emissions have been mitigated by about 36575 tones. (EFDRE, MFED, 2010)

The aim of the Ethiopia government in undertaking biofuel development include: To substitute fossil fuels used in transport, to leverage biofuel's suitability to assist with rural development, both for local energy consumption purposes and to establish a new production industry, to promote a climate friend energy source and for maximize the financial benefits to farmers (UNCT Ethiopia, 2008). 


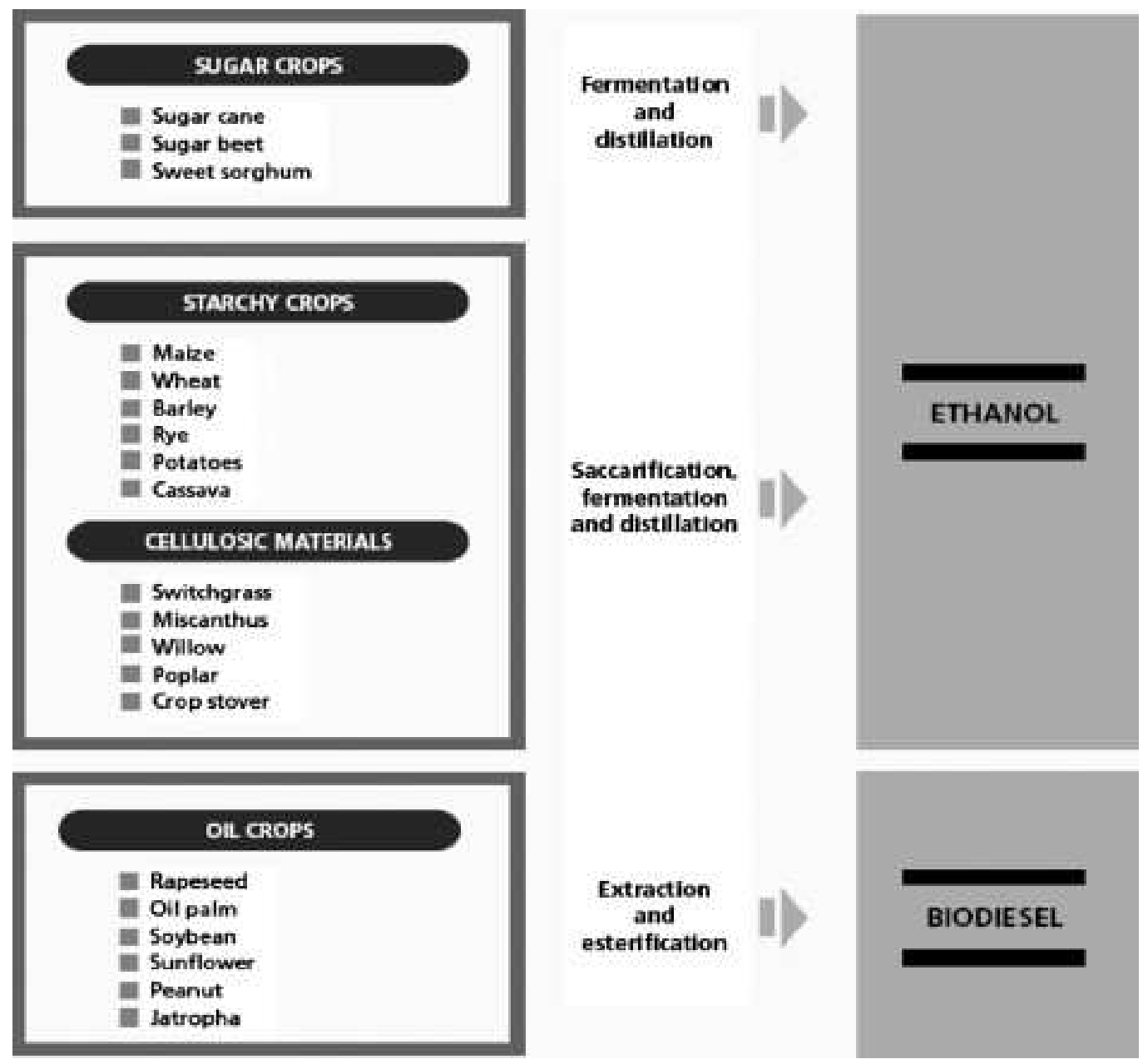

Source: FAO (2008)

Fig. 1. Biofuel crops, feed-stocks and fuels.

The strategic directions during GTP period are development of renewable energy, expansion of energy infrastructure, and creation of an institutional capacity that can effectively and efficiently manage such energy sources and infrastructure. During GTP period, the gap between energy demand for and supply of electricity will be minimized. Per capita consumption of electric city of households is expected to increase during the GTP period. In order to promote and realize the country's green development strategy, ongoing initiative to generate electricity from hydropower and renewable energy source like biofuel, solar and wind will be remain the strategic direction of GTP period. In addition new technological innovations will be utilized to insure that the energy sub-sector's doesn't emit additional carbon dioxide. The distribution of wood saving materials and technologies throughout the county will be continued (GTP Ethiopia, 2000).

Ethiopia emmision of $\mathrm{CO}_{2}$ are very low compare to developed countries. Novertheless, access to a range of reliable, affordable and clean energy sources is criteria for susutanable growth. One of the potential means to realize the shift to more sustainable fuel is the production of biofuel and other renwable energy source, as part of ethiopia's green development strategy.as stated in the biofuel development strategy, ethiopia has sutaible land for biofuel( bio ethanol and biodesel) developpmet. Implementing a biofuel development initiative, in line with country's green development, will enable bio fuel to substitute for imported petroluem fuel even significant for export.more over job will be created locally at different stage of biofuel production process and thus contrubute to raizing living standards. Action will be taken to expand bio-fuel plantations,intruducing use of bio-fuel in house holds for cooking and lightining, standardize and refine information relating to land, technologies and markets for bio-fuel development, and promote knowlegde about biofuel use in each region. Benefite of biofuel development include inprove carbon sink of ethiopia, reduction deforestation and reduction in time spent on and burden to wemen and children in searching firewood.

The bio-fuel development program will implement strategies during the paln period to creat a network of 
implementing abencies, research institues and unversities to adopt and promote sustaianble development of biofuel tecknology. The network will collect and organize data on bio-fuel land, technologies and markets, coordinate involvement of relevant stockholders, support and motivate private investors' involvement in the bio-fuel development activities, involve farmer in production and supply of biodiesel by coordinating the network of relevant extension services, and facilitate experience sharing with countries where bio-fuel development is at more advanced stage of development (GTP Ethiopia, 2000).

\subsection{Biofuel Development in Ethiopia}

Biofuel is not directly related to electricity issues but considering the current situation that

$90 \%$ of energy consumption is supplied by wood or dung; biofuel can be an alternative to improve energy efficiency. Also, the export of biofuel could be an important source of foreign currency for Ethiopia, where there is currently no significant fossil fuel production.

This is important for Ethiopia particularly at the moment when the oil price surge is hitting the country's balance sheet. Ministry of energy and mining and other government agencies are starting to promote biofuel development now.

\subsubsection{Policy}

The Ethiopian Government plans to allocate 2,300ha for biofuel production counting on a big EU market as well as domestic demand. However, even Brazil, which is the most advanced country in biofuel development and which possesses 8 times more land than Ethiopia, has developed less than 2,300ha for biofuel so far. Therefore, the number might not be realistic but it shows the enthusiasm of the government.

\subsubsection{Biodiesel}

Biodiesel is made of Jetropha and Castor Oil. Since harvesting of these fruits cannot be mechanized, it requires a lot of manpower. The production cost can be minimized in Ethiopia, which possesses a plentiful workforce at a reasonable price. In addition to the labor cost, the land is leased by the government for a very low price, which also reduces the cost.

On the other hand, the transportation cost is an issue. Harar, which is the highest potential area for biodiesel production, and the second candidate site, Welo, is relatively near to the

Djibouti port, but the rest of the candidate sites are more than $1,000 \mathrm{~km}$ from the port and the transportation cost would be substantial. One of the solutions is to sell the products on the domestic market near the production sites.

Castor Oil is in higher demand not only for biodiesel but also for medicines, lubricants and cosmetics. Therefore, it would be relatively expensive for biodiesel (1,500 US \$/ t), while Jetropha costs only 1,000 US $\$ / t$, which gives it a higher potential as material for biofuel.

$50 \%$ of the weight of a Castor fruit can be processed to crude oil, compared to only $33-38 \%$ in case of the Jetropha.
The productivity improvement of Jetropha is ongoing.

\subsubsection{Bio-ethanol}

Bio-ethanol can be made of sugar cane. $8 \mathrm{mln}$ Litter of ethanol is currently produced annually from sugar cane in Ethiopia and bio-ethanol has been starting to be mixed with petrol at the rate of 5\% since October 2008. According to ministry of , the usage area and the ratio will be gradually expanded.

Ethanol is more efficient than wood and dung, so it is good to promote ethanol usage at home as a short term measure. Some are already using bio-ethanol for cooking at home.

Also, a joint venture of American and Ethiopian companies is producing a cooking stove using ethanol, which may gradually increase the domestic demands (Embassy of Japan in Ethiopia, 2008).

\subsection{Current Biofuels Development Status in Ethiopia}

In order to ensure the country's continued development program, the national fuel security and environmental sustainability, it is important to increase fuel utilization and satisfy the demand partly by locally produced fuels such as biofuel. "The Ethiopian Biofuel Development and Utilization Strategy" is targeted to supply fuels from locally produced biofuel (Jatropha, Castor bean, Palm oil and sugar cane) and the objective of the strategy is to ensure the production of biofuel without affecting food self sufficiency, to improve balance of payment and to reduce environmental impacts. The strategy sets out that

106,997 million tons of ethanol from sugar cane will be produced by 2016 (nearly 7 times of the annual gasoline consumption of the country). The strategy also stipulates that with the participation of 1.25 million farmers in Jatropha biodiesel production the imported 1 billion liters of petrol diesel per annum can be substituted. By involving biodiesel producing companies the production will be in excess of local consumption and it will be a good commodity for export (MME, 2007).

Biofuels development as a primary product was first initiated by the private sector when Sun Biofuels Ethiopia (National Biodiesel Corporation), a subsidiary of a UK based private limited company, was allocated the first land for cultivation of jatropha for production of biodiesel in Benshangul Gumuz regional state in 2006. The coming of Sun biofuels awakened other players in the sector, including the government, the private sector, NGOs and civil society organizations. As the first project in the country, there were several drawbacks in the legal process of business formation and actual implementation of the project in the field. Since then several private companies have come to the scene. Fincha Sugar Factory, however, has been producing bioethanol as a by-product MELCA.

Several local and international private and non-private biofuels developers have registered in Ethiopia. Most of these companies have the intention of going for large-scale commercial development. Currently there are over 50 developers registered for the cultivation of energy crops for biodiesel production. For bioethanol, however, there are only six developers in the 
country of which four of them are government owned sugar estates. At present only one of the sugar estates, Fincha, is producing ethanol. The rest are at the pre-implementation stage either retrofitting existing factories for ethanol development (MELCA Mahiber, 2008).

According to MELCA only five regions were identified to conduct a brief assessment about the current development of biofuels in Ethiopia. These regions are identified based on the current trend of biofuels development expansion in the country.

So far, as shown above table 1,327,094 ha of land have already been allocated for investors. Over $80 \%$ of these developments are happening in arable land, forest land and woodlands. Many of these companies are still requesting for more lands for further expansion of biofuels production, in and around their current production sites.

Table 1. Regional distribution of biofuels energy company name and land hold within region in the country.

\begin{tabular}{|c|c|c|c|c|c|}
\hline NO. & Company Name & Region & Land acquired (ha) & Out Growers Land(Ha) & crop type \\
\hline 1 & Sun Biofuels Eth/NBC & Benshangul & 80,000 & & Jatropha \\
\hline 2 & Amabasel Jatroph Project & Benshangul & 20,000 & & Jatropha \\
\hline 3 & Jatropha Biofuels Agro Industry & Benshangul & 100,000 & & Jatropha \\
\hline 4 & IDC Investment & Benshangul & 15,000 & & Jatropha \\
\hline 5 & ORDA & Amahara & 884 & & Jatropha \\
\hline 6 & BDFC Ethiopia Industry & Amahara & 18,000 & 30,000 & Sugarcane/sugar beat \\
\hline 7 & Jemal Ibrahim & Amahara & 7.8 & & Castor bean \\
\hline 8 & A Belgium Company & Amahara & 2.5 & & Castor bean \\
\hline 9 & Flora Eco Power Ethiopia & Oromia & 10,000 & 5,000 & Castor bean \\
\hline 10 & $\begin{array}{l}\text { Petro Palm Corporation } \\
\text { Ethiopia }\end{array}$ & Oromia & 50,000 & & Castor/Jatropha \\
\hline 11 & VATIC International Business & Oromia & 20,000 & & NA \\
\hline 12 & Global Energy Ethiopia & SNNPR & 2,700 & 7,500 & Castor bean \\
\hline 13 & OmoSheleko Agro Industry & SNNPR & 5,500 & & palm \\
\hline 14 & Sun Biofuels Eth/NBC & SNNPR & 5,000 & & Jatropha \\
\hline Total & & & 327,094 & 42,500 & \\
\hline
\end{tabular}

\subsection{Socio Economic Importance of Biofuel}

\subsubsection{Land Inventory}

There is a pressing need to clearly identify the availability of land for biofuel development, subjected to ownership, ecogeographical and food supply constraints. There is, in principle, considerable land available for biofuel production in Ethiopia but it is not clear that the actual status of the areas considered having potential. This need to be investigates as priority as it will be more difficult to obtain certification for Ethiopia biofuel if the land use impact associated with their production.

\subsubsection{Maintenance and Sustaniability}

Biodiversity -as with new agro-economic system, growing a biofuel crop will alter local habitates and resources that will affect speciess' distrubution and aboundance.

\subsubsection{The Food Verse Fuel Dilemma}

Biofuel production can increase the demand for agricultural input such as land and water, and this can jeopardize the production of food. In principle the scaling up of agricultural crops for biofuels can be done without competing with food production and without resulting forest clearance.

Biofuels will increase the price food because either food crops are converted to fuel or energy crops displace food crops on agricultural lands. The ultimate impact on a region will depend on several factors including the intensity of cultivation of biofuel crops and the extent of trade in food- related commodities. One can envision several scenarios. Developed regions such as the EU and the United States will experience price increase but may be able to absorb the price rise more easily than developed countries. One reason for this could be that since food-processing costs comprise a large share of the total cost, there will be a lesser impact on the final consumer price. The food processing industry will, however, be negatively affected due to higher input costs and lower demand for food. Developing countries that are net importers of food will be negatively affected due to higher food prices irrespective of whether they adopt biofuels or not. A region that is autarkic and does not adopt biofuel crops should, however, be isolated from such developments. If biofuel crops are cultivated exclusively on set-aside lands or marginal lands, with little competition with food crops, the impacts on food prices can be theoretically minimal. But in reality biofuels may still compete for other resources like water or labor and thus impact food production (UNCT Ethiopia, 2008).

\subsection{Drivers for Biofuels}

Increasing consensus about the end of cheap oil, the risks to supply due to political instability in major oil-producing regions, and the consequences of carbon emissions from fossil fuels have caused a spurt in the search for alternative sources of oil (Runge, 2007). But today, plant-based fuels like ethanol and biodiesel seem to be emerging as a serious alternative fuel ahead of technologies. According to runge, there are several reasons for the excitement surrounding biofuels. 
1. Biofuels are replenishing: Biofuels are an inexhaustible resource since the stock can be replenished through agriculture.

2. Biofuels can reduce carbon emissions: Biofuels are sometimes considered as a solution to climate change. While this may be too optimistic, it is true that direct carbon emissions from combustion of biofuels are insignificant compared to fossil fuels. That said, it is hard to generalize about indirect carbon emissions (from agriculture and processing) and emissions of other harmful pollutants, which can be significant.

3. Biofuels can increase farm income: Today decline in farm income is a problem the world over (Gardner, 2003). With biofuels, most countries will be able to grow one or more types of crops in which they possess a comparative advantage and use them to meet either domestic or foreign demand or both. This increased demand for agriculture is expected to increase farm income.

4. Biofuels can improve energy security: The fact also means that countries can produce their own fuel, and reduce their dependence on foreign sources for energy (Hazell and Pachauri 2006).

5. Biofuels can create new jobs: Biofuels are more labor intensive than other energy technologies on per unit of energy delivered basis (Kammen, Kapadia, and Fripp 2004). The production of the feedstock and the conversion require greater quantities of labor compared to that required for extraction and processing of fossil fuels or other industrially based technologies like hydrogen and electric vehicles.

6. Biofuels have physical and chemical properties similar to oil: Several physical and chemical characteristics of biofuels such as their liquid state, specific energy density, viscosity, and combustion characteristics are more similar to gasoline or diesel than for alternatives. They are combustible in existing internal combustion engines with minor modifications. As a result, adapting to biofuel-based infrastructure (at least at low levels of blending like $10 \%$ or $20 \%$ ) can be achieved more cost effectively than adapting to hydrogen, battery, or natural gas-based automobiles (Ugarte, 2006).

Biofuels are simple and familiar: biofuels have an aura of being simple and familiar to consumers, producers, and policymakers alike. Ethanol has been used as an additive or as a blend with gasoline in several countries for over two decades

\subsection{Biofuel Sources and Conversion Technologies}

Like any production system, inputs like fuel, capital, and labor are combined to produce the energy using a chemical conversion process. In the process pollution and other useful crop products are also produced. Table 3 shows the key differences between traditional and modern bioenergy systems in terms of these inputs, conversion technology, and the outputs. Traditional forms of biomass use are characterized by low capital, low conversion efficiency, poor utilization of fuel, and poor emission controls whereas modern forms of biomass use are characterized by higher capital, higher conversion efficiency, better utilization of fuel, and better emission controls (WorldBank,2007).

\subsubsection{Traditional Biomass}

Traditional biomass implies the use of sources like wood, crop residues, animal dung, and charcoal for cooking and heating at the household level. This is often done using three stone stoves or in some cases using improved cook stoves or biogas stoves. Traditional use of biomass has the following characteristics. Firstly, traditional biomass is usually gathered or collected (often by women and children) from common lands or privately owned lands and are therefore largely an informal activity. The only cost to users is the opportunity cost of time invested in collecting fuel wood.

Second, combustion of biomass is characterized by low efficiency due to poor design of stoves. As a result, biomass is overused and is associated with deforestation, fodder scarcity, and depletion of soil quality (due to non availability of animal manure and other residues for soil). Third, uncontrolled and open burning of biomass in traditional stoves, in poorly ventilated chambers has serious health implications for women and children (Kammen 2005).But such attributes are not inherent to bioenergy and are the consequence of socio-economic and political factors, which can be addressed with the aid of appropriate policies. For example, dissemination of improved cook stoves and biogas systems, better ventilation in the kitchen area, sustainable harvesting of wood, etc., can make traditional biomass more sustainable (Kammen, 2006). Investments in improving the efficiency and reducing emissions from traditional biomass use will have impacts as wide ranging as improving gender equity and halting environmental degradation given its high use of child and women labor and the high fuel use per unit of delivered energy.

\subsubsection{Modern Biofuels}

Liquid biofuels for transportation like ethanol and biodiesel are one of the fastest-growing sources of alternative energy in the world today and are poised to reverse the historical trend of decline in the share of biomass in the global primary energy supply. Like traditional biomass, modern biofuel systems also encompass a variety of feedstock, conversion technologies. They are used mostly for generation of electricity or transportation as opposed to cooking and heating. The technological and commercial maturity and scalability of the various biofuel pathways are also diverse. Sugar and starch-based crops and the associated conversion technologies are the most mature for ethanol production today, while oilseed crops are the most mature sources of biodiesel. But since they have low yield per hectare and are also used for food, they are not well suited for large-scale expansion. Cellulose-based fuels are considered the most promising for the future but are not commercially and technically mature today. The production of electricity from biomass, using wood and agricultural and municipal wastes while technologically mature, is not commercially widespread. The reasons for low commercial maturity are several including high cost, under compensation 
for environmental benefits, etc. (Roos, 1999).

\subsection{Major Types of Biofuels}

A variety of biofuels can be derived from biomass. Ethanol and biodiesel are the most widely used biofuels for transportation today. In the future, butanol and Fischer-Tropsch fuels have the potential to become competitive as liquid fuels. Synthesis gas produced by gasification of wood is used mainly for electricity generation. Fuelwood and biogas produced by anaerobic digestion of plant and animal wastes are used for cooking and heating at the household level.

The term feedstock refers to the raw material used in the conversion process, which can be a crop, crop residue, or agricultural and municipal waste. The main types of feedstock are described in detail below

1. Sugar and starch-based crops: Crops rich in sugar and starch like sugarcane and corn (maize), respectively, supply almost all the ethanol that is produced today. Other major crops being used include wheat, sorghum, sugar beet, and cassava.

Technologies for conversion of sugar and starch are also the most technologically and commercially mature today. The major drawback of such crops is that they are important food crops and their use for fuel can have adverse impacts on food supply. Another drawback is these crops are intensive in the use of one or more among inputs like land, water, fertilizer, pesticides, etc., which have other environmental implications (Pimentel and Patzek 2005; Ulgiati 2001; Giamipietro, Ulgiati, and Pimentel 1997; Farrell 2006). In the future cellulosic sources are expected to displace such crops as the major source of ethanol.

2. Oilseed crops: In contrast to ethanol, biodiesel is produced from oilseed crops like soybean, rapeseed, and oil palm (Demirbas 2001, Sheehan 2000). But like sugar and starch crops, oilseed crops are also characterized by low yield and high use of inputs. In the future non edible crops like Jatropha curcas and Pongamia pinnata, which are considered to be low-input and suited to marginal lands, may become major sources of biodiesel especially in the dry and semi-arid regions of Asia and Africa. But the economic viability of crops these crops under conditions of low inputs and poor land quality are considered highly uncertain (Prayas, 2007).

3. Wood: Wood is predominantly used for cooking and heating at the household level and to a lesser extent for producing electricity at a small scale. When used directly at the household level, it is often collected from forests or other lands. Commercial plantations of woody trees like poplar and willow in temperate zones and eucalyptus and acacia exist today albeit on a small scale. The predominant use of commercial plantations today is for the supply of wood to paper and pulp industries (Ravindranath and Hall, 1995). Future cellulosic technologies, which permit the conversion of wood to ethanol, may compete with current uses of wood.

4. Wastes and residues: According to Kim and Dale (2004), there are about 73.9 Million tonnes of dry wasted crops and about 1.5 billion tonnes of dry ligno-cellulosic biomass from seven crops namely, maize, oats, barley, rice, sorghum, wheat, and sugarcane (Kim and Dale, 2004). These could potentially yield about 490 billion liters of ethanol or about $30 \%$ of global gasoline use today. Furthermore, lignin-rich fermentation residue, which is the crop product of ethanol made from crop residues and sugarcane bagasse, can potentially generate both 458 TWh5 of electricity (about $3.6 \%$ of world electricity production) and. The utilization of this feedstock is contingent upon the successful commercialization of cellulosic technologies. The economics of collection and processing of residues is also not clear. The low specific energy density of residues can imply high transportation costs that might render a large fraction of this resource uneconomical (OECD, 2006).

5. Dedicated cellulosic crops: Cellulose is the substance that makes up the cell walls of plant matter along with hemicellulose and lignin. It is the primary structural component of green plants comprising more than $50 \%$ of the phyto-matter incorporated annually in plants (FAO, 2007). It is much more abundant than starch, sugar, and oil, which are concentrated only in seeds and fruits. Perennial grasses like switchgrass and Miscanthus are two crops considered to hold enormous potential for ethanol production. Perennial crops also confer other advantages like lower rates of soil erosion and higher soil carbon sequestration. However, technologies for conversion of cellulose to ethanol are just emerging and not yet technically or commercially mature. Cellulose conversion technologies will allow the utilization of non grain parts of crops like corn stover, rice husk, sorghum stalk, bagasse from sugarcane, and the woody parts (Wyman, 1999 and Lynd, 1996)

\subsection{Conversion Technologies}

A number of conversion technologies are available depending on the types of feedstock, fuel, and end use that are desired (Faaij 2006). We will provide a brief review of each of these conversion technologies.

Direct combustion: This is the most common and oldest form of conversion that involves burning organic matter in an oxygen-rich environment mainly for the production of heat. The most common use of this heat is in the production of steam for industrial use or for electricity generation. In some cases, the goal of burning might simply be reduction in the volume of waste without energy recovery as is the case with disposal of agricultural or medical waste. Examples of applications of direct combustion include burning of biomass like wood, dung, and agricultural wastes in homes for cooking and heating, co-firing of biomass with coal in electricity production, the burning of wood for process heat in chemical industries, etc. Typical flame temperatures for combustion and incineration range between $1,500^{\circ} \mathrm{F}$ and $3,000^{\circ} \mathrm{F}$ (Demirbas 2001).

Thermo-chemical conversion: In contrast to direct combustion, thermo-chemical conversion utilizes heat and pressure in an oxygen-deficient environment to produce "synthesis gas". Syn-gas is composed mainly of carbon monoxide and hydrogen, and can either be combusted to produce heat or converted to other fuels like ethanol and 
hydrogen. Thermo-chemical conversion is cleaner compared to other conversion pathways. Thermo-chemical conversion pathways include processes such as gasification, pyrolysis, plasma arc, and catalytic cracking. A detailed description of these technologies can be found in a report on conversion technologies by the California Integrated Waste Management Board (CIWMB). While gasification processes vary considerably, typical gasifiers operate from $1,300^{\circ} \mathrm{F}$ and higher and from atmospheric pressure up to five atmospheres or higher (CIWMB, 2005).

Biochemical conversion: Unlike thermal and thermochemical processes, biochemical conversion processes occur at lower temperatures and have lower reaction rates. Higher moisture feedstock is more easily converted through biochemical processes. Fermentation and anaerobic digestion are two common types of biochemical conversion processes. The main use of fermentation is in conversion of sugar and starch, found in crops like sugarcane, corn, wheat, etc., to ethanol. The fermentation of alcohol yields coproducts like distiller dried grains, which can be used as feed for livestock. Anaerobic digestion involves the bacterial breakdown of biodegradable organic material in the absence of oxygen over a temperature range from about $50^{\circ}$ to $160^{\circ} \mathrm{F}$. The main end product of these processes is called biogas, which is mainly methane $(\mathrm{CH} 4)$ and carbon dioxide $\left(\mathrm{CO}_{2}\right)$ with some impurities such as hydrogen sulfide $\left(\mathrm{H}_{2} \mathrm{~S}\right)$. Biogas can be used as fuel for engines, gas turbines, fuel cells, boilers, and industrial heaters, and as a feedstock for chemicals (with emissions and impacts commensurate with those from natural gas feedstock) (Demirbas, 2001and CIWMB, 2005). Conversion of cellulosic feedstock using acid or enzymatic hydrolysis is another type of biochemical process, which is expected to become commercially very important in the future.

Transesterification: This is the most common method of producing biodiesel today.

Transesterification is a chemical process by which vegetable oils (like soy, canola, palm, etc.) can be converted to methyl or ethyl esters of fatty acids also called biodiesel. Biodiesel is physically and chemically similar to petro-diesel and hence substitutable in diesel engines. Transesterification also results in the production of glycerin, a chemical compound with diverse commercial uses. This process is carried out at a temperature of $60^{\circ} \mathrm{C}$ to $80^{\circ} \mathrm{C}$ (Demirabas 2001, 2003; Sheehan 2000; Crabbe2001).

\section{Emerging technologies}

A variety of other technologies for conversion of biomass to fuels, or substitutes for fossil fuel-derived products like plastics, is being researched and developed.

Cellulosic ethanol: Cellulosic conversion implies the transformation of nongrain or nonfruit parts of phytomatter, which are mostly comprised of cellulose such as the stem, wood, grass, leaves, etc., into ethanol. Switchgrass and Miscanthus are two perennial grasses that are undergoing trials as feedstock while a variety of chemical and biochemical processes including acid-based and enzymatic processes, are being developed simultaneously for breaking down cellulose into ethanol. Similar to sugar refineries that utilize bagasse for cogeneration of electricity, cellulosic conversion can also be accompanied by the combustion of lignin to supply heat and steam for conversion. This will have the added benefit of offsetting electricity produced from fossil fuels (Lynd, 1996).

Fischer-Tropsch fuels: These are synthetic substitutes to gasoline and diesel, which are produced by a process in which carbon monoxide and hydrogen are catalytically transformed into liquid hydrocarbons (HC). Although coal and natural gas are considered as the main sources for carbon monoxide and hydrogen, gasification of biomass feedstock is considered a more environmentally benign conversion pathway for Fischer-Tropsch fuels (Hamelinck 2004). Another line of research involves production of "biocrude" through high-temperature/ pressure and chemical breakdown of biomass into liquids, using hydrothermal upgrading (HTU) or pyrolysis. All these pathways are currently expensive and technically immature (Fulton 2005).

Biobutanol: Biobutanol is butanol (i.e., butyl alcohol), which is produced biologically from biomass through a process called acetone butanol ethanol (ABE) fermentation. As a result of low butanol yield, $\mathrm{ABE}$ fermentation was considered uneconomical. However, it is expected to be viable at a gasoline price of $\$ 3.00$ per gallon or greater (Ramey 2004).

Algae biodiesel: Biodiesel production from algal oil is another technology, which is considered to have significant potential to replace diesel use. However, the major difficulties are in finding an algal strain with a high lipid content and fast growth rate that isn't too difficult to harvest, and has a cost-effective cultivation system (Sheehan 1998).

Biobased products and bioplastics: Agricultural feedstock can also be used to produce other industrial products called bioproducts and bioplastics, which are substitutes to chemicals, plastics, hydraulic fluids, and pharmaceuticals produced from fossil fuels. Agricultural feedstock which are considered as candidates for making such products, include a variety of crops, wood and plant oils, and agricultural and forestry residues. Bioproducts are considered to require less energy to produce than the fossil and inorganic products they replace (USDA, 2007).

\subsection{Estimates of Future Potentials for Bioenergy}

There are several studies that estimate the global potential of biofuels in absolute units of energy and as percentages of global energy that they can supply. Estimates of such potential can be classified into three categories, namely, biophysical, technical, and economic. Each category in the list comprises the ones following it, so that the three categories are of decreasing magnitude. Biofuels can in principle supply a large fraction of global energy need, and this is called the theoretical potential. The biophysical potential is determined primarily by natural conditions and describes the amount of biomatter that could be harvested at a given time. The technical potential depends on the available technologies and therefore evolves as technology progresses. Estimates of biophysical and technical potential vary depending on assumptions about land availability, yield 
levels in energy crop production, future availability of forest wood and of residues from agriculture and forestry, etc. The economic potential depends on at least two additional factors, namely, energy prices and policies toward renewable and clean technologies. However, oil prices are uncertain with respect to time, while policies vary both with time and also from region to region (Fischer and Schrattenholzer 2001). As a result, economic potential is hard to predict. For example, Brazilian ethanol is economically viable when oil sells at $\$ 35$ per barrel whereas U.S. ethanol is viable only at around $\$ 50$ per barrel (Ugarte 2006, OECD 2006).

Most studies report an increase in the supply of bioenergy over time. A review of 17 earlier studies on this subject by Berndes, Hoogwijk, and van den Broek (2003) reveals that estimates for potential contribution of biomass in the year 2050 range from below $100 \mathrm{EJ} / \mathrm{yr}$ to over $400 \mathrm{EJ} / \mathrm{yr}$ (Berndes, Hoogwijk, and van den Broek 2003). In comparison to the current level of bioenergy of $45 \mathrm{EJ} / \mathrm{yr}$, this represents a doubling to a tenfold increase. A study by the International Institute of Applied Systems Analysis and the World Energy Council predicts that bioenergy would supply $15 \%$ of global primary energy by 2050 (Fischer and Schrattenholzer 2001). A study by the Natural Resources.

Defense Council predicts that an aggressive plan to develop cellulosic biofuels between now and 2015 could help the United States produce the equivalent of nearly 7.9 million barrels of oil per day by 2050 . This is equal to more than $50 \%$ of the current total oil use in the transportation sector (Greene 2004). A majority of the increase is accounted by cellulosic biomass like switchgrass. However, it is also possible to envision scenarios that involve reduction in cropland while meeting the future food needs for a larger and wealthier population. One of the drawbacks of the above assessment is that it is static and does not take into account future changes in technologies and the demand for food. An analysis of the demand for cropland based on fundamental forces responsible for expansion of cropland by Waggoner and Ausubel (2001) suggests that sustained technological progress in crop production could meet the recommended nutritional requirements for a population of 9 billion and simultaneously reduce cropland by 200 million hectares by the year 2050. It is even claimed that under the best-case scenario the land withdrawn from agriculture could be as high as 400 million hectares. At the same time, they warn that such improvements would come about only through sustained investments in productivity, experimentation, and deployment of better technologies (Waggoner 1996, Waggoner and Ausubel 2001).

\subsection{Diverse Solutions for a Diverse World}

Biofuels have played a vital role in meeting the energy needs of human beings. There is reason to believe they will continue to do so in the future albeit in a different manner.

Traditional forms of biomass energy are still prevalent among the rural poor in developing countries that use it for cooking and heating. Modern forms of bioenergy are expanding in the developed countries largely for use in automobiles and electricity generation. With economic growth, the share of traditional biomass will decline while that of modern energy sources will increase so that transportation and electricity production may be the dominant end uses one day as opposed to cooking and heating.

However, given the slow pace of expansion of rural electrification and access to clean cooking fuels in developing countries, such a change may be a long while coming.

Traditional or modern, biofuels can make a positive contribution to all three pillars of sustainable developmenteconomic, social, and environmental. But the diversity in the social, economic, and environmental impacts proscribes a "one size fits all" approach.

Most people contend that no single source of biomass or conversion technology or type of biofuel will suffice because of the disparate agro-climatic, ecological, technological, and socioeconomic and political economic factors that need consideration. Modern biofuels can in some cases be more detrimental to the poor than traditional biofuels. The appropriation of food crops for ethanol production may have adverse impacts of food prices (Runge 2007, Msangi 2006, OECD 2006, FAPRI 2005). The commercialization of cellulosic technologies may result in conversion of fodder resources for livestock or conversion of wood used by household into fuel for automobiles. The use of marginal lands for biofuel plantations can also worsen the energy poverty of the landless poor who would lose access to fuelwood and fodder from such lands (Gundimeda 2004, Rajagopal2007, Karekezi and Kithyoma 2006). In the case of poor rural households in developing countries, the use of biomass for providing cleaner energy for cooking and providing electricity may be more beneficial overall rather than using them to produce transportation fuels8. Along with technological progress, innovative policies will be necessary to ensure a smooth transition to a future where modern biofuels can be a significant supplier of energy. This chapter has provided a historical and technological perspective. In the following chapters, we will discuss the environmental, economic, and political aspects of biofuels.

\subsection{Biofuels Climate Mitigation Potential}

One of the major arguments behind support for biofuels is the perception that they are more climate friendly than oil. Biofuels are sometimes even claimed as being carbon neutral and fossil free. (Pimentel and Patzek 2005, Farrell 2006). In reality, biofuels consume a significant amount of energy that is derived from fossil fuels. Inputs to production include tillage, fertilizers, pesticides, irrigation, operation of machinery for harvesting and transport, steam and electricity for processing, etc., all of which embody fossil energy, leading to a significant net carbon addition to the atmosphere by the time the biofuel is ultimately consumed (Giampietro 1997, Lal 2004, Pimentel and Patzek 2005, Farrell 2006). Equally important is the fact that production of biofuels has other.

Nonclimate-related environmental impacts such as soil erosion due to tilling, eutrophication due to fertilizer runoffs, impacts of exposure to pesticides, habitat, and biodiversity 
loss due to land-use change, etc., which have not received the same attention as GHG emissions (Fearnside 2002, Curran 2004). In fact, already the fear of rainforest destruction due to the EU's biofuel mandate led commissioner Peter Mandelson to recently declare, "Europeans won't pay a premium for biofuels if the ethanol in their car is produced unsustainably by systematically burning fields after harvests, or if it comes at the expense of rainforests. We can't allow the switch to biofuels to become an environmentally unsustainable stampede in the developing world." Given these trade-offs, characterizing the overall environmental impact of biofuels is complex and challenging. (Nan Shi, Doris Chen Yu, Hui (Becky) Li 2009).

Biofuels benefit environmental by reducing GHGs and reducing local pollution, Bioethanolis water soluble, non toxic and biodegradable, Ethanol can replace $10 \%$ of the world's gasoline without clearing more rainforests and by doing less harm to the environment than current agriculture, Biofuels offer low levels of carbon dioxide emission, Hydrocarbon - based fuels produce greater noxious by productions like carbon monoxide compared to biofuel which produces compounds like nitrogen oxides; but the biofuel by product is less dangerous to human health and the environment, Fossil fuels: derived from long dead biological materials. Therefore, biofuel has huge potential of mitigation of climate change by substitute the oil and petroleum that import from foreign and maximize Ethiopia economy.

\section{Conclusion}

Concerns about climate change, security, and reliability of energy supply and the growing demand for oil are likely to make biofuel sever more attractive. As far as energy is concerned, the main contribution of biofuel will be in augmenting the supply of fuels for transportation, for electricity and heat. For the most part, the future of biofuels will depend on energy policies and technologies that will affect demand for liquid fuels. Increase in fuel efficiency, hybrid and fuel cell vehicles, and carbon taxes will reduce the demand for fuel, while increase in income and highways will increase the demand for fuel. Such increases are more certain in developing countries like Ethiopia.

A major motivation for biofuel is that they will raise farm income, which will have attendant political and economic benefits. But such gains may not be realized when domestic production competes with imports that are cheaper. This is the reason biofuel crops like other agricultural goods are also subject to barriers in the form of duties, quotas, and bans on imports. The rationale for such protection can be several such as the need to support domestic farmers, enable the development of a domestic infant industry, keeping food prices low, and environmental regulation.

Biofuels will have both environmental benefits and costs. They may reduce carbon emissions, but there will be negative impacts on agricultural activity.

The use of marginal lands or the utilization of crop residues for biofuel production will deny access to fuel wood and fodder, which can hurt the poor. In such cases the production of biomass suited to local needs may be socially more optimal than the production of biofuels for cars in cities. Demand-side policies that discourage the consumption of fossil fuels or carbon emissions as a way of improving energy security or protecting the environment seem should also be given greater attention by researchers and policymakers despite the political economic barriers to such policies.

Reduce fossil fuel imports-The use of ethanol can reduce the use of gasoline. A reduction in the use of gasoline reduces some of the dependence on unstable foreign sources of oil. Because the biofuel feed stock can easily obtain from Ethiopia then the oil from biofuel can process in Ethiopia. Ethiopia lost a lot of money in each year due to importing oil and pollute the environment from the emission of the oil but biofuel energy is make reverse.

There is Health benefits from reduced global warming since biofuel energy is free from emitting gas to the atmosphere as comparing oil that formerly used in Ethiopia. There has to be some kind of regulation to make sure there is no greater deforestation, land degradation of low - fertility tropical soils, and concomitant rise in $\mathrm{CO}_{2}$ output.

\section{Recommendation}

- More research is required on crops, grass, woods etc that are not used or competition for food.

- Determination of the amount of carbon sequesters or sinks by the biofuel comparing petroleum and coal that currently Ethiopia used are essential.

- Policy and Strategies will be required to tackle the competition between the food dilemma and biofuel energy production especially Energy and Environment Policies of Ethiopia should look at carefully to overcome the problem.

- Most of biofuel producers have lack of knowledge on processing, cultivation and value chain therefore Technical Knowledge and awareness is required.

- Jatropha can be easily grown in Ethiopia since it is used as a fence at this moment, it need further replication and propagation in large amount and should start production of ethanol to overcome the problems of energy fuel.

- There is cost and energy when biofuel feed stocks is producing. Therefore, the amount of emission gas should calculate.

\section{References}

[1] Embassy of Japan in Ethiopia, 2008. Study on the Energy Sector in Ethiopia. Addis Ababa, Ethiopia.

[2] Gardner, B., 2003. "Fuel Ethanol Subsidies and Farm Price Support: Boon or Boondoggle?" working paper, Department of Agricultural and Resource Economics, University of Maryland. 
[3] Green Alliance, 2013, The global green race: a business review of UK competitiveness in low carbon markets.

[4] Hazell, P., and R. K. Pachauri (eds.) 2006. Bioenergy and Agriculture: Promises and Challenges. International Food Policy Research Institute 2020.

[5] Intergovernmental Panel on Climate Change, 2014, Climate Change 2014: impacts, adaptation and vulnerability.

[6] International Renewable Energy Agency, November 2012, Renewable power generation costs: summary for policymakers.

[7] Kammen, D., K. Kapadia, and M. Fripp 2004. "Putting Renewables to Work: How Many Jobs Can the Clean Energy Industry Generate," report of the Renewable and Appropriate Energy Laboratory, Energy and Resources Group/Goldman School of Public Policy at University of California, Berkeley.

[8] Martinot, E. Renewables 2005: Global Status Report. World watch Institute, 2005.

[9] MELCA Mahiber 2008. Rapid Assessment of Biofuels Development Status in Ethiopia and Proceedings of the National Workshop on Environmental Impact Assessment and Biofuels, Addis Ababa, Ethiopia.

[10] MelisTeka, 2006 .Energy Policy of Ethiopia. Addis Ababa, Ethiopia.

[11] Ministry of Mines and Energy Ethiopia, 2008. Ethiopian Biofuels Development and Utilization Strategym, Addis Ababa, Ethiopia.

[12] MME (Ministry of Mines and Energy), 2007. The Biofuel Development and Utilization Strategy of Ethiopia. Addis Ababa, Ethiopia.

[13] Nan Shi, Doris Chen Yu, Hui (Becky) Li, 2009. Introduction to Biofuel.

[14] OECD, 2014, The cost of air pollution.
[15] Rebecca Willis, 2014. Paris 2015: getting a global agreement on climate change. Published by Green Alliance August 2014 Green Alliance, Buckingham Palace Road London. www.green-alliance.org.uk (Access October 2, 2015).

[16] Rebecca Willis, 2014. Paris 2015 Getting a global agreement on climate change. Christian Aid, Green Alliance, Greenpeace, RSPB, and WWF

[17] Review of Environmental, Economic and Policy Aspects of Biofuels Deepak Rajagopal and David Zilberman, the World Bank, 2007.

[18] Roos, A., R. L. Graham, B. Hektor, and C. Rakos.1999. "Critical Factors to Bioenergy Implementation," Biomass and Bioenergy 17,: 113-126.

[19] Runge, C., and B. Senauer, (2007). "How Biofuels Could Starve the Poor," Foreign Affairs.

[20] Tobin, J., 2005. Lifecycle Assessment of the production of Biodiesel from Jatropha. An Msc Thesis presented to the School of Construction Management and Engineering of Reading University.

[21] Ugarte, D. G. de la Torre. 2006. "Developing Bioenergy: Economic and Social Issues," Bioenergy and Agriculture: Promises and Challenges, International Food Policy Research Institute 2020 Focus No. 14.

[22] UNCT ethiopia, 2008. Biofuel a vaibe alternative source of energy? knowledge sharing forum UN ethiopia.

[23] UNEP, November 2010, The emissions gap report: are the Copenhagen Accord pledges sufficient to limit global warming to 2 degrees $\mathrm{C}$ or 1.5 degrees $\mathrm{C}$ ?

[24] WBCSD and EEA (The World Business Council for Sustainable Development \& the International Energy Agency), 2004. The IEA/SMP Transportation Model. 